\title{
A novel family VII esterase with industrial potential from compost metagenomic library
}

\author{
Chul-Hyung Kang ${ }^{1,2,3}$, Ki-Hoon Oh' ${ }^{1}$, Mi-Hwa Lee ${ }^{1,2}$, Tae-Kwang Oh ${ }^{1}$, Bong Hee Kim ${ }^{3^{*}}$ and Jung- Hoon Yoon ${ }^{1,2^{*}}$
}

\begin{abstract}
Background: Among the vast microbial genomic resources now available, most microbes are unculturable in the laboratory. A culture-independent metagenomic approach is a novel technique that circumvents this culture limitation. For the screening of novel lipolytic enzymes, a metagenomic library was constructed from compost, and the clone of estCS2 was selected for lipolytic properties on a tributyrin-containing medium.

Results: The estCS2 sequence encodes a protein of 570 amino acid residues, with a predicted molecular mass of $63 \mathrm{kDa}$, and based on amino acid identity it most closely matches (45\%) the carboxylesterase from Haliangium ochraceum DSM 14365. EstCS2 belong to family VII, according to the lipolytic enzyme classification proposed by Arpigny and Jaeger, and it retains the catalytic triad $\operatorname{Ser}_{245}-\mathrm{Glu}_{363}-\mathrm{His}_{466}$ that is typical of an $\alpha / \beta$ hydrolase. The $\mathrm{Ser}_{245}$ residue in the catalytic triad of EstCS2 is located in the consensus active site motif GXSXG. The EstCS2 exhibits strong activity toward p-nitrophenyl caproate (C6), and it is stable up to $60^{\circ} \mathrm{C}$ with an optimal enzymatic activity at $55^{\circ} \mathrm{C}$. The maximal activity is observed at $\mathrm{pH}$ 9, and it remains active between $\mathrm{pH}$ 6-10. EstCS2 shows remarkable stability in up to $50 \%(\mathrm{v} / \mathrm{V}$ ) dimethyl sulfoxide (DMSO) or dimethylformamide (DMF). The enzyme has the ability to cleave sterically hindered esters of tertiary alcohol, as well as to degrade polyurethanes, which are widely used in various industries.

Conclusions: The high stability of EstCS2 in organic solvents and its activity towards esters of ketoprofen and tertiary alcohols, and in polyurethane suggests that it has potential uses for many applications in biotransformation and bioremediation.
\end{abstract}

\section{Background}

Discovering microorganisms and their encoded enzymes, and characterizing their interactions, are one of the main purposes in studying microbial diversity. However, it is commonly thought that only $1-10 \%$ of the total microorganisms in most environmental samples can be cultured under laboratory conditions. The study of those remaining, known as "unculturables," is important to understand the genetic diversity, population structure, and ecological roles of microbes and to find ways of utilizing them as a novel source of molecules with unique properties [1]. In recent decades, the investigation by function- and sequence- based screening of the entire

\footnotetext{
* Correspondence: bhkimnh@cnu.ac.kr; jhyoon@kribb.re.kr

'Bioindustry and Bioenergy Research Center, Korea Research Institute of Bioscience and Biotechnology (KRIBB), 125 Gwahangno, Yuseong, Daejeon, Republic of Korea

${ }^{3}$ College of Pharmacy, Chung Nam National University, Daejeon 305-764,

Republic of Korea

Full list of author information is available at the end of the article
}

microbial genome collected directly from a specific environment, the so-called metagenome, has gained much attention as an approach to gather otherwise inaccessible information about microbial communities from various environments as well as to obtain valuable enzymes [2,3].

Composting is a biological decomposition and humification of organic matter by microorganisms. During the thermogenic phase of the composting process, the temperature usually rises up to $80^{\circ} \mathrm{C}$ for a certain period, and thermophiles belonging to genus Thermus or Bacillus have been isolated from such material [4,5]. Many enzymes released by microorganisms, such as cellulases, hemicellulases, proteases, phosphatases, arlylsulphatases, and lipases, play key roles in the composting process [6]. Therefore, most of enzymes have thermostable characteristics.

Lipases (EC 3.1.1.3) and esterases (EC 3.1.1.1) are $\alpha / \beta$ hydrolases that are produced by many microorganisms 
as well as by eukaryotes. Lipases catalyze the hydrolysis and synthesis of relatively long-chain triacylglycerols, whereas esterases catalyze the reactions involving shortchain triacylglycerols [7,8]. Microbial lipases and esterases classically have been classified into 8 families (Families I-VIII). Recently, additional families were described on the basis of the conserved sequence motifs and biological properties of novel lipolytic enzymes discovered from metagenomic libraries from various environments, such as tidal flat sediment $[9,10]$, surface sea water [11], and deep sea sediment [12,13]. A lipolytic enzyme contains a catalytic triad formed by Ser, His, and Asp/Glu residues, and the Ser residue is usually conserved in the GXSXG pentapeptide motif [14]. Some of the known lipolytic enzymes are stable in various organic solvents, have highly specific chemo-, regional-, and enantioselectivity, and they may be used in the resolution of racemic mixtures and synthesis of pharmaceuticals and new surfactants by bioconversion of oils, fats, etc. $[7,15]$. Interestingly, some esterases degrade polyurethane, which is a hydrophobic synthetic polymer. For example, Comamonas acidovorans TB-35 and Pseudomonas chlororaphis encode esterases that can degrade this polymer $[16,17]$.

In this study, we report the screening of a metagenome library, constructed from compost, and the isolation of a unique thermostable lipolytic enzyme. We identified the esterase as belonging to family VII, and we describe the biochemical characterization of purified protein.

\section{Results}

Screening of esterase clones and DNA sequence analysis Screening a metagenomic fosmid library for esterasepositive clones was conducted by identifying the areas of halo formation around bacterial colony margins on the tributyrin agar plates. Ten of the positive clones were identified among approximately 13,000 chloramphenicol-resistant recombinant clones, and one of these positive clones was selected for further study.

In order to find the gene encoding lipolytic activity within the fosmid, subcloning of randomly digested DNA fragments, generated by partial Sau3AI digestion of the fosmid, and activity screening of the subclones, were performed. One open reading frame, designated estCS2, was identified. DNA sequence analysis revealed that estCS2 consists of 1,713 bp that encode a protein of 530 amino acids, with a predicted molecular weight of $63 \mathrm{kDa}$.

The amino acid sequence of EstCS2 exhibits 45\% identity and $58 \%$ similarity to a carboxylesterase from Haliangium ochraceum DSM 14365 (Genbank: ACY17267), $40 \%$ identity and $52 \%$ similarity to a carboxylesterase from Acidovorax delafieldii 2AN (Genbank:EER61780.1), and 39\% identity and 52\% similarity to a polyurethane esterase from Delftia acidovorans (Genbank:BAA76305). The catalytic triad of EstCS2 was identified as $\mathrm{Glu}_{363}-\mathrm{His}_{466}-\mathrm{Ser}_{375}$ ( $\mathrm{Ser}_{375}$ is contained within the classical GXSXG pentapeptide motif at amino acid positions 373-377), through multiple sequence alignment with closely related homologues $[14,18]$. Phylogenetic analysis of EstCS2 and other lipases reveals that EstCS2 belongs to family VII (Figure 1)[13].

\section{Cloning of estCS2, and overexpression and purification of the enzyme}

E.coli BL21(DE3) was transformed using a recombinant plasmid constructed from pET-estCS2 and inserted estCS2 sequences (pET-estCS2). Following induction, the encoded EstCS2 was expressed in an active form in the soluble fraction of the host cells. By purification on nickel-nitrilotriacetic acid (Ni-NTA) resin, EstCS2 was purified at a $41 \%$ yield from the soluble fraction, and the specific activity was increased to approximately 6 -fold. By sodium dodecyl sulfate-polyacrylamide gel electrophoresis (SDS-PAGE) analysis under denaturing conditions, the enzyme has an apparent molecular mass of $55 \mathrm{kDa}$. The N-terminal sequence of EstCS2 was determined to identify them. N-terminal amino acid sequencing of purified EstCS2 allowed the identification of 5 amino acid residues, $\mathrm{D}_{60} \mathrm{DREP}_{65}$. The lipolytic activity of the protein was confirmed by a zymogram on an indicator plate, as a clear band corresponding to a size of $55 \mathrm{kDa}$.

\section{Characterization of esterase EstCS2}

Because the sequence of EstCS2 is closely related to the polyurethane esterase from Deftia acidvorans TB-35, polyurethane-degrading activity of EstCS2 was determined on an indicator plate containing poly(diethylene glycol adipate)(poly DEGA). The purified EstCS2 formed a clear zone on the indicator plate, indicating the enzyme can hydrolyze poly DEGA. EstCS2 also formed a clear zone on a lipolytic activity indicator plate containing tributyrin as the substrate (Figure 2).

Enzyme specificity with respect to the length of the acyl chains in the substrate was investigated using $p$-nitrophenyl esters as substrates. The esterase showed highest activity with $p$-nitrophenyl caproate (pNPC, C6) among the $p$-nitrophenyl esters tested, while $p$-nitrophenyl esters with long-chain acyl groups were not hydrolyzed efficiently. Results of measuring free fatty acids released enzymatically, which was monitored by change in $\mathrm{pH}$, also showed that EstCS2 has high lipolytic activity toward short chains, especially tributyrin (C4) (Figure 3).

Effect of temperature on the activity of EstCS2 was investigated over a range of $10-80^{\circ} \mathrm{C}$, and these experiments indicated that EstCS2 has an optimal activity at $55^{\circ} \mathrm{C}$ and exhibits $50 \%$ of the maximal activity at $80^{\circ} \mathrm{C}$. 
a
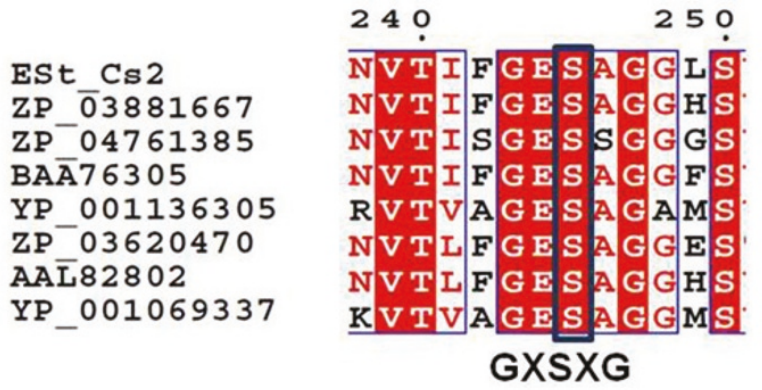

b

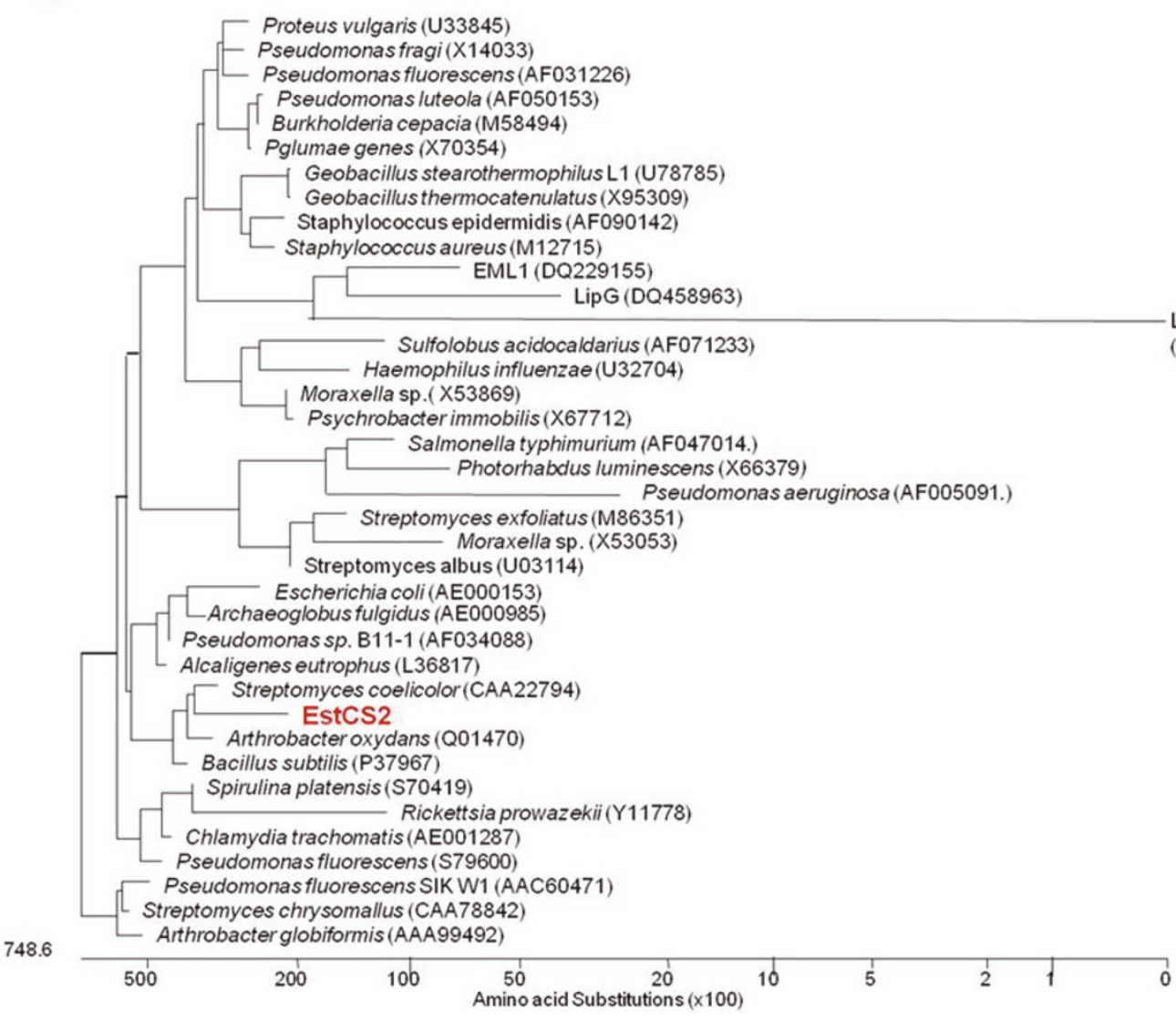



E
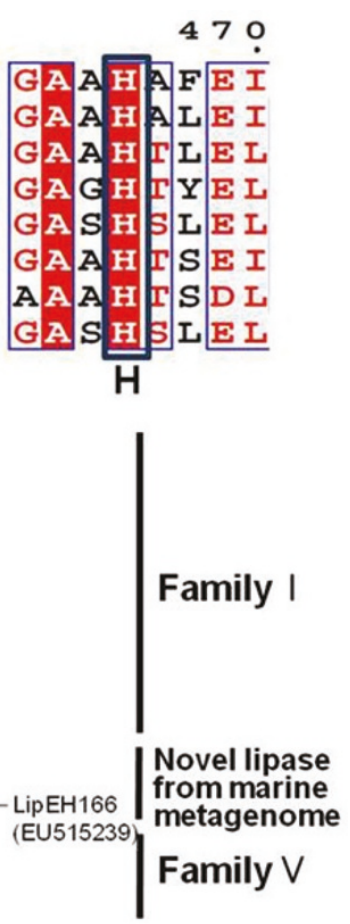

Family II

Family III

Family IV

Family VII

Family VI

Family VIII

Figure 1 Multiple amino acid sequence alignments and phylogenetic analysis of EstCS2. (a) Multiple amino acid sequence alignments of EstCS2 and its homologs. ZP_03881667, carboxylesterase from Haliangium ochraceum DSM 14365; ZP_04761385, Carboxylesterase from Acidovorax delafieldii 2AN; BAA76305, polyurethane esterase from Delftia acidovorans YP_001136305, carboxylesterase from Mycobacterium gilvum PYR-GCK; ZP_03620470, Carboxylesterase from Tolumonas auensis DSM 9187 AAL82802, paraben-hydrolyzing esterase precursor from Enterobacter cloacae; YP_001069337, carboxylesterase, from Mycobacterium sp. JLS. (b) Phylogenetic tree based on amino acid sequence of EstCS2 and closely related proteins. Phylogenetic analysis was performed using the program MEGALIGN (DNASTAR, Madison, WI). Except EstCS2, protein sequences for previously identified families of bacterial lipolytic enzymes were retrieved from GenBank (http://www.ncbi.nlm.nih.gov). The units at the bottom of the tree indicate the number of substitution events.

Thermostability data showed that EstCS2 is stable up to $60^{\circ} \mathrm{C}$, but this stability decreases sharply at temperatures above $70^{\circ} \mathrm{C}$ (Figure 4a). This activity at high temperatures is a common feature of thermostable enzymes [19]. In order to determine the optimal $\mathrm{pH}$ for the esterase, we measured the activity of EstCS2 at various $\mathrm{pH}$ values (pH 7-11), using $\mathrm{pNPC}$ as a substrate, at $25^{\circ} \mathrm{C}$.
EstCS2 exhibited the highest activity at $\mathrm{pH}$ 9.0, and the esterase was found to be stable within a wide $\mathrm{pH}$ range (pH 6.0-10.0) (Figure 4b).

\section{Effect of additives}

Various detergents, such as $0.1 \%(w / v)$ Tween 20, Tween 40, Tween 80, Triton X-100, Na-taurocholate, 


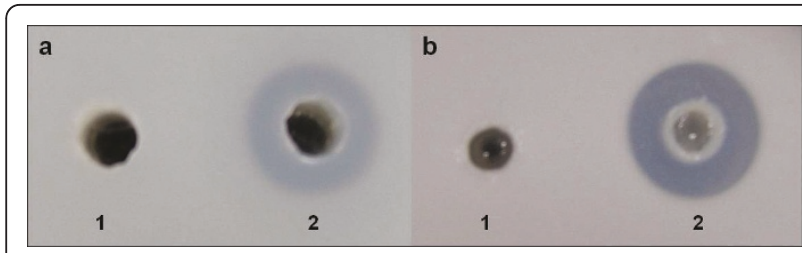

Figure 2 Plate assay for degradation of polyurethane and triglyceride by EstCS2. (a) polyurethane degrading activity plate, (b) lipolytic activity plate, 1. Crude cell extract of E.coli BL21(DE3)/ pET22b, 2. Purified EstCS2.

Na-deoxycholate, and CHAPS, slightly increased enzyme activity, while $1 \%(\mathrm{w} / \mathrm{v})$ SDS reduced the activity by about $12 \%$. The effects of divalent metal ions on EstCS2 activity were tested, which revealed that $1 \mathrm{mM} \mathrm{CaCl}_{2}$ slightly increases the activity (119\%), and $10 \mathrm{mM} \mathrm{FeSO}_{4}$ is inhibitory.

To investigate the amino acid residues involved in catalysis, the inhibitory effect of various chemical modifiers was examined. The activity of EstCS2 was inhibited by phenylmethylsulfonyl fluoride (PMSF), as are other lipolytic enzymes that contain a serine residue in the active site in a conserved pentapeptide GXSXG [20].

The effect of organic solvents on the activity of EstCS2 To test the effect of solvents on esterase activity, various solvents were added to the enzyme reaction, at final concentrations of 10,20 , and $50 \%(\mathrm{v} / \mathrm{v})$ of the total volume. In $10 \%(\mathrm{v} / \mathrm{v})$ of water-miscible solvents (polar solvents), with the exception of acetone, esterase activity was either increased or retained stable. Addition of $50 \%$ (v/v) DMSO did not affect esterase activity, while addition of $50 \%(\mathrm{v} / \mathrm{v})$ methanol, ethanol, 2-propanol, 1-butanol, or acetonitrile decreased enzymatic activity dramatically (Table 1 ).



Figure 3 Substrate specificity of EstCS2 toward various triacylglycerols and $p$-nitrophenyl esters.
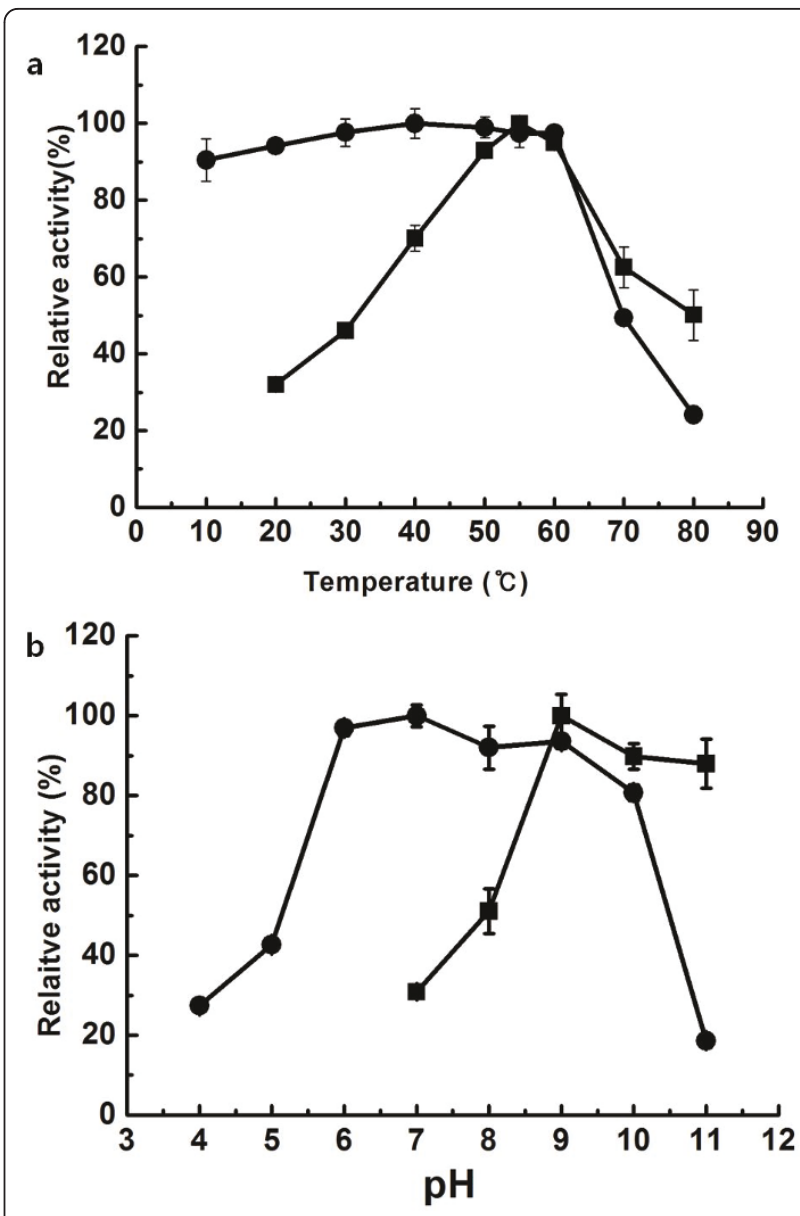

Figure 4 Effect of temperature and $\mathrm{pH}$ on the activity of EstCS2. (a) Enzyme activity was measured at each temperature under standard assay condition (-). In addition, the enzyme was preincubated at the indicated temperature, and the remaining activity was determined $(\bullet)$. (b) Enzyme activity was measured at each $\mathrm{pH}$ under standard assay conditions (- $\mathbf{(})$. In addition, the enzyme was preincubated at the indicated $\mathrm{pH}$, and the remaining activity was determined $(\bullet)$.

Hydrolysis of tertiary alcohol esters and ketoprofen ethyl ester by EstCS2

The ability of EstCS2 to hydrolyze esters of tertiary alcohols (TAs) was examined using linalyl acetate as a substrate. Thin-layer chromatography (TLC) analysis showed that EstCS2 converts linalyl acetate to linalool (Figure 5). The ability of EstCS2 to cleave sterically hindered esters of tertiary alcohol is remarkable. Enantioselectivity of EstCS2 was determined using racemic $(\mathrm{R} / \mathrm{S})$-ketoprofen ethyl ester as a substrate. The timedependent and substrate concentration-dependent enzymatic assay revealed that EstCS2 simultaneously hydrolyzes (R)-ketoprofen ethyl ester and (S)-ketoprofen ethyl ester, with a modest preference toward (R)ketoprofen ethyl ester $\left(\mathrm{ee}_{\mathrm{p}}=-0.07 \%\right.$; ee\%: enantiomeric excess). 
Table 1 Effect of various organic solvents on EstCS2 activity

\begin{tabular}{cccc}
\hline Compound & \multicolumn{3}{c}{ Remaining activity (\%) at concentration (\%) of } \\
\cline { 2 - 4 } & $\mathbf{1 0}$ & $\mathbf{2 0}$ & $\mathbf{5 0}$ \\
\hline Control & 100 & 100 & 100 \\
Methanol & 119.9 & 101.4 & 12.6 \\
Ethanol & 117.3 & 138.2 & 8.7 \\
2-propanol & 132.5 & 131.3 & 4.7 \\
1-butanol & 99.3 & 98.2 & 2.4 \\
Acetonitrile & 118.3 & 92.1 & 4.4 \\
DMSO & 125.9 & 128.2 & 97.4 \\
Acetone & 44.8 & 15.6 & 3.3 \\
DMF & 110.3 & 115.1 & 50.9 \\
\hline
\end{tabular}

\section{Discussion}

We isolated a gene (estCS2) belonging to family VII from a metagenome library constructed from compost. Amino acid sequence analysis of EstCS2 exhibited the conserved sequence motifs of esterase/lipase, GXSXG, and putative catalytic triad composed of $\mathrm{Ser}_{245}$, Glu 363 , $\mathrm{His}_{466}$. EstCS2 preferred short-chain $p$-nitrophenyl esters as substrate, and it has optimal activity at $\mathrm{pH}$ 9.0 and $55^{\circ} \mathrm{C}$. The enzyme is stable up to $60^{\circ} \mathrm{C}$. This suggests that EstCS2 is an esterase which originates, most likely, from a thermostable microorganism in compost soil.



Figure $\mathbf{5}$ TLC analysis of enzymatic conversion of racemic linalyl acetate to linalool. The reaction was initiated by enzyme addition. lane 1, linalyl acetate ester; lane 2, linalool; lane 3, no enzyme added; lane 4, reaction time of 1 h; lane 5 reaction time of 5 h; lane 6 , reaction time of $10 \mathrm{~h}$.
EstCS2 formed a clear zone on an indicator plate containing poly DEGA, which is one of components of polyester polyurethane. Therefore, EstCS2 seems to possess the ability to hydrolyze polyester polyurethane, although further enzymatic studies of polyurethane degradation are needed. The characterization of the polyurethanase is important for future research aimed at the development of new bioremediation techniques [21].

TAs and their esters are useful building blocks in chemistry, and they are regarded as important compounds from natural products to pharmaceuticals [22]. TLC analysis indicated that EstCS2 hydrolyzes esters of tertiary alcohol, such as linalyl acetate. Extensive amino acid sequence analysis showed that EstCS2 has a GGG (A)X motif, composed of $G_{160} G A F$ sequence. Lipolytic enzymes that possess a GGG(A)X motif at an oxyanion hole near the active site are active towards TAs, while most lipolytic enzymes with the more common GX motif cannot convert tertiary alcohol esters into TAs [22-24]. EstCS2 can also hydrolyze (R/S)-ketoprofen ethyl ester, with greater enantioselectivity for the (R)enantiomer. In pharmaceutical applications, ketoprofen is one of the non-steroidal anti-inflammatory drugs (NSAID) with analgesic, antipyretic, and antiinflammatory effects and is known to inhibit the production of prostaglandins. Specifically, (S)-ketoprofen is a main compound associated with these effects, while the (R)ketoprofen has unwanted side effects. Therefore, in order to use EstCS2 for the production of (S)-ketoprofen, (S)-specific enantioselectivity of EstCS2 would need to be improved through a directed evolutionary method, or structure-based rational design [25].

EstCS2 is stable in organic solvents. The discovery of natural enzymes that are stable in organic solvents is essential for their use in the chemical industry, but their discovery should also be accompanied with the development of biological, physical, and chemical methods [26].

In summary, a novel thermostable esterase, EstCS2, which belongs to family VII, was isolated from a compost metagenome library. EstCS2 has high stability in organic solvents; it can degrade polyurethane and hydrolyze ketoprofen ethyl ester and tertiary alcohol ester. These are very useful characteristics for biotechnological processes. This study demonstrates that the metagenomic approach is a useful technique to discover novel enzymes with potential for industrial applications.

\section{Materials and methods}

Screening of the esterase gene from a compost metagenomic fosmid library

Metagenomic DNA from compost soil was extracted as previously described [27], and it was used to construct a metagenomic library using the CopyControl ${ }^{\mathrm{TM}}$ fosmid library production kit (Epicentre, USA), according to the 
manufacturer's instructions. Activity-based esterase/ lipase screening was performed to identify recombinant clones with lipase activity. The transformants were spread on Luria-Bertani (LB) agar plates containing chloramphenicol $(25 \mu \mathrm{g} / \mathrm{mL}), 1 \%(\mathrm{v} / \mathrm{v})$ tributyrin $(\mathrm{C} 4)$ as a substrate, and $0.5 \%(\mathrm{w} / \mathrm{v})$ gum arabic. Active colonies producing clear halos on the plates were selected, and the lipolytic genes were sequenced from the fosmids of active colonies by a random shotgun sequencing method. The open reading frame (ORF) of the esterase was compared with reference sequences that were retrieved from protein and nucleotide databases on the Entrez server at the NCBI (http://www.ncbi.nlm.nih.gov/ sites/entrez/). Sequence similarity searches were performed using the BLAST 2.0 program, and multiple alignments were conducted with highly similar sequences with the CLUSTAL W program. A phylogenetic tree was constructed with the MEGALIGN program (DNA STAR Inc., USA).

\section{Cloning and overexpression of the estCS2 gene}

The putative esterase gene was amplified by PCR with 2 primers (5'-GGGCATATGATGCGAGCCGAGTTGC-3' and 5'-GCGCTCGAGTGATTTTTGGGGATCT-3'; the underlined sequences indicate the NdeI and $\mathrm{XhoI}$ recognition sites, respectively). PCR products were digested with $N d e \mathrm{I}$ and $\mathrm{XhoI}$, and then, they were ligated into the pET-22b $(+)$ vector (Novagen, Germany) that had been digested with the same restriction enzymes. The recombinant DNA was transformed into $E$. coli BL21 (DE3).

Transformants were cultured in LB liquid medium containing ampicillin $(100 \mu \mathrm{g} / \mathrm{mL})$ at $37^{\circ} \mathrm{C}$. When the optical density of the culture reached an absorbance of around 0.6 at $600 \mathrm{~nm}, 0.5 \mathrm{mM}$ isopropyl- $\beta$-d-thiogalactopyranoside (IPTG) was added for the induction of protein expression, and the transformants were incubated for additional $18 \mathrm{~h}$ at $21^{\circ} \mathrm{C}$. The cells were harvested by centrifugation at $7,000 \mathrm{rpm}$ at $4^{\circ} \mathrm{C}$ for $10 \mathrm{~min}$ and then resuspended in binding buffer $(50 \mathrm{mM}$ Tris$\mathrm{HCl}$ at $\mathrm{pH} 8.0$, containing $300 \mathrm{mM} \mathrm{NaCl}$ ). The resuspended cells were disrupted by sonication, and the crude cell lysate was centrifuged at $16,000 \mathrm{rpm}$ for 30 min; the supernatant, which constitutes the cell extract, was withdrawn. The cell extract was applied to a column containing Ni-NTA resin (QIAGEN GmbH, Germany). After washing with 25 column volumes of the binding buffer containing $2 \mathrm{mM}$ imidazole, bound proteins were eluted with binding buffer containing 250 $\mathrm{mM}$ imidazole. Eluted fractions were concentrated by centrifugation at $500 \times g$ at $4^{\circ} \mathrm{C}$. Concentrated proteins were loaded onto a gel filtration column, Superdex 200 10/300 GL (GE Healthcare, USA), equilibrated with 50 $\mathrm{mM}$ Tris- $\mathrm{HCl}$ buffer (pH 8.0) containing $300 \mathrm{mM} \mathrm{NaCl}$, and separation was conducted at a flow rate of $0.5 \mathrm{~mL} /$ min on a BioLogic DuoFlow Chromatography System (Bio-Rad Laboratories, USA). The resulting protein fractions were analyzed by SDS-PAGE in $10 \%$ polyacrylamide gels.

\section{$\mathrm{N}$-terminal amino acid sequence analysis}

$\mathrm{N}$-terminal amino acid sequence analysis was performed on proteins that had been separated by SDS-PAGE and electrotransferred to PVDF membrane (Pro Blott; Applied Biosystems, USA). The gel was electroblotted at $50 \mathrm{~mA}$, for $60 \mathrm{~min}$ using freshly prepared $10 \mathrm{mM} \mathrm{3-}$ (cyclohexylamino)-1-propanesulfonic acid (CAPS) buffer at $\mathrm{pH} 10$ and $10 \%(\mathrm{v} / \mathrm{v})$ methanol (HPLC grade) in distilled water as a blotting buffer. Subsequently, the gel was stained with Coomassie brilliant blue to confirm effective transfer. After blotting, selected protein bands were cut from the membrane, and $\mathrm{N}$-terminal sequence analysis was carried out using an automatic protein sequencer (Applied Biosystems, USA).

\section{Plate assay for degradation of polyurethane and triglyceride}

Activity of the EstCS2, to degrade polyurethane as substrate, was tested on an indicator plate. The polyurethane esterase indicator plate was prepared with a sonicated emulsion of $0.5 \%$ poly DEGA in $20 \mathrm{mM}$ Tris$\mathrm{HCl}$ at $\mathrm{pH} 8.0$ [16]. The lipolytic activity indicator plate contained emulsified tributyrin. A crude cell extract of E.coli BL21(DE3)/pET22b, and purified EstCS2, were transferred into holes in the plates, and each plate was incubated for $5 \mathrm{~h}$ at ambient temperature.

\section{Characterization of EstCS2}

Substrate preference toward $p$-nitrophenyl esters (C2C18) was determined enzymatically by measuring the amount of $p$-nitrophenol released by hydrolysis. Absorbance was continuously measured at $405 \mathrm{~nm}$ for $4 \mathrm{~min}$, using a DU800 spectrophotometer (Beckman, USA). As a standard assay solution, a mixture (1:4:95, by vol) of $10 \mathrm{mM} p$-nitrophenyl caprylate (C8), ethanol, and 100 mM GTA buffer was used. One unit of enzyme activity was defined as the amount of enzyme needed to release $1 \mu \mathrm{mol}$ of $p$-nitrophenol per min at $25^{\circ} \mathrm{C}$. Protein concentration was determined according to the method of Bradford (Bio-Rad Protein Assay), using bovine serum albumin as the standard. Substrate specificities toward various triacylglycerols were measured by titrating free fatty acid released by substrate hydrolysis. Substrates were emulsified in a solution containing $10 \mathrm{mM} \mathrm{NaCl}, 1$ $\mathrm{mM} \mathrm{CaCl} 2$, and $0.5 \%(\mathrm{w} / \mathrm{v})$ gum arabic solution. The substrate emulsion $(30 \mathrm{~mL})$ was adjusted to $\mathrm{pH} 8.0$ with $10 \mathrm{mM} \mathrm{NaOH}$, and the reaction was initiated by adding purified enzyme. The $\mathrm{pH}$ of the reaction was recorded 
by a pH-stat (842 Titrando; Metrohm, USA), equipped with thermostat and stirrer, at $25^{\circ} \mathrm{C}$ for $6 \mathrm{~min}$. One unit of esterase activity was defined as the amount of enzyme that liberates $1 \mu \mathrm{mol}$ of fatty acid per min.

The optimum $\mathrm{pH}$ for enzyme activity was determined at $25^{\circ} \mathrm{C}$ in $100 \mathrm{mM}$ GTA buffer, in the $\mathrm{pH}$ range 4.0 11.0. $\mathrm{pH}$ stability of the esterase was determined by incubating the enzyme in $100 \mathrm{mM}$ GTA buffer (from $\mathrm{pH} 4-11$ ) for $16 \mathrm{~h}$ at $4^{\circ} \mathrm{C}$, and residual activity was measured at $25^{\circ} \mathrm{C}$. To determine the optimum reaction temperature, the reaction mixture was incubated for $10 \mathrm{~min}$ at various temperatures $\left(10-80^{\circ} \mathrm{C}\right)$. Thermostability of the esterase was determined by preincubation for $1 \mathrm{~h}$, over a temperature range of $10-80^{\circ} \mathrm{C}$, in $100 \mathrm{mM}$ GTA buffer ( $\mathrm{pH} 9.0$ ); subsequently, residual activity was measured at $25^{\circ} \mathrm{C}$.

To measure the effects of detergents on the esterase activity, aliquots of purified enzyme, mixed with various detergents and metal ions, were incubated in $100 \mathrm{mM}$ GTA buffer ( $\mathrm{pH} 9.0)$ at $30^{\circ} \mathrm{C}$ for $1 \mathrm{~h}$. After incubation, residual activity was measured under standard assay conditions.

The effect of several inhibitors (at $1 \mathrm{mM}, 5 \mathrm{mM}$, and $10 \mathrm{mM}$ ), such as PMSF, dithiothreitol (DTT), ethylenediaminetetraacetic acid (EDTA), and 2-mercaptoethanol were tested by incubation with the enzyme for $1 \mathrm{~h}$ at $30^{\circ} \mathrm{C}$. The stability of the enzyme in the presence of organic solvents was tested with $10 \%, 20 \%$, and $50 \%$ (w/ v) of methanol, ethanol, 2-propanol, 1-butanol, acetonitrile, dimethyl sulfoxide (DMSO), acetone, and dimethylformamide (DMF) by incubation of the enzyme for $1 \mathrm{~h}$ at $30^{\circ} \mathrm{C}$ in various organic solvent dilutions.

\section{Hydrolysis of linalyl acetate and ketoprofen ethyl ether by EstCS2}

The reaction mixture, containing rac-linalyl acetate (15 $\mathrm{mg} / \mathrm{mL})$ and the purified protein $(10 \mathrm{mg} / \mathrm{mL})$ in $50 \mathrm{mM}$ Tris- $\mathrm{HCl}(\mathrm{pH} 8.0)$, was agitated on a rotary shaker $(200$ $\mathrm{rpm}$ ) at ambient temperature. The reaction was stopped by the addition of 4 volumes of ethanol, and insoluble material was removed by centrifugation. Samples were periodically withdrawn and analyzed by TLC using Merck silica gel $60 \mathrm{~F}_{254}$, and petroleum ether:ethyl acetate $(5: 1)$ as an eluent. Compounds were visualized by spraying with a solution of $5 \mathrm{~g}$ vanillin/L concentrated $\mathrm{H}_{2} \mathrm{SO}_{4}$ and subsequently heating.

(R/S)-Ketoprofen alkyl ester was synthesized by a general method for esterification. (R/S)-Ketoprofen (12 g) was solubilized in $100 \mathrm{~mL}$ of $100 \%$ ethanol in a roundbottom flask. $\mathrm{H}_{2} \mathrm{SO}_{4}$ was then added as a catalyst for esterification. The mixture was refluxed for $6 \mathrm{~h}$ at $70^{\circ} \mathrm{C}$, with stirring, for the synthesis of ketoprofen ethyl ester. Sodium acetate $(0.5 \mathrm{~g})$ was added to quench the catalyst, the residual alcohol was removed by vacuum evaporation, and the esterified material was washed 3 times with aqueous $1 \mathrm{M} \mathrm{NaHCO}_{3}$ to remove unreacted ketoprofen, sulfuric acid, and ethanol [28]. The hydrolytic activity, using the $(\mathrm{R} / \mathrm{S})$-ketoprofen ethyl ester as substrate, was determined at $30^{\circ} \mathrm{C}$ for $24 \mathrm{~h}$ with the purified enzyme $(6 \mathrm{mg} / \mathrm{mL})$ in a reaction mixture containing $50 \mathrm{mM}$ Tris- $\mathrm{HCl}(\mathrm{pH}$ 8.0). The reaction was stopped by the addition of 1 volume of ethanol, and insoluble material was removed by centrifugation. The resulting solution was then analyzed for conversion yield and enantioselectivity by high performance liquid chromatography (HPLC). The concentrations of (R/S)-ketoprofen ethyl ester, (R)-ketoprofen and (S)-ketoprofen were determined using an HPLC system (Hitachi, Japan). The column used was a chiral compound analytical column (Chirex Phase 3005; Phenomenex). Methanol containing $30 \mathrm{mM}$ ammonium acetate was used as the mobile phase. The column was run at a constant flow rate $(1.5 \mathrm{~mL} / \mathrm{min})$, and the eluent was monitored spectrophotometrically at $254 \mathrm{~nm}$. One unit of enzyme activity was defined as the amount of enzyme producing $1 \mu \mathrm{mol}$ of ketoprofen per min under the specified conditions.

\section{Nucleotide sequence accession number}

The nucleotide sequence data of the esterase gene (estCS2) has been deposited in Gen Bank, under the accession number GU256649.

\section{Acknowledgements}

This work was supported by the 21C Frontier Program of Microbial Genomics and Applications (grant 11-2008-002-00) from the Ministry of Education, Science \& Technology (MEST) of the Republic of Korea, and by grant from the KRIBB Research Initiative Program.

\section{Author details}

${ }^{1}$ Bioindustry and Bioenergy Research Center, Korea Research Institute of Bioscience and Biotechnology (KRIBB), 125 Gwahangno, Yuseong, Daejeon, Republic of Korea. ' $U$ niversity of Science \& Technology (UST), 217 Gajungro, Yuseoung, Daejeon, Republic of Korea. ${ }^{3}$ College of Pharmacy, Chung Nam National University, Daejeon 305-764, Republic of Korea.

\section{Authors' contributions}

CHK conducted the design of experiments, carried out the study, and drafted the manuscript. $\mathrm{KHO}$ and $\mathrm{MHL}$ assisted in the analysis of data and reviewed the manuscript. TKO participated in the design of experiments and helped to draft the manuscript. JHY and BHK conceived this study and are responsible for the design and drafting of the manuscript. All authors read and approved the final manuscript.

\section{Competing interests}

The authors declare that they have no competing interests.

Received: 25 February 2011 Accepted: 29 May 2011

Published: 29 May 2011

\section{References}

1. Cowan D, Meyer Q, Stafford W, Muyanga S, Cameron R, Wittwer P: Metagenomic gene discovery: past, present and future. Trends Biotechnol 2005, 23(6):321-329. 
2. Schmeisser $C$, Steele $H$, Streit WR: Metagenomics, biotechnology with non-culturable microbes. Appl Microbiol Biotechnol 2007, 75(5):955-962.

3. Lorenz P, Liebeton K, Niehaus F, Eck J: Screening for novel enzymes for biocatalytic processes: accessing the metagenome as a resource of novel functional sequence space. Curr Opin Biotechnol 2002, 13(6):572-577.

4. Beffa T, Blanc M, Lyon PF, Vogt G, Marchiani M, Fischer JL, Aragno M: Isolation of Thermus strains from hot composts (60 to 80 degrees C). Appl Environ Microbiol 1996, 62(5):1723-1727.

5. Poli A, Romano I, Caliendo G, Nicolaus G, Orlando P, Falco A, Lama L, Gambacorta A, Nicolaus B: Geobacillus toebii subsp. decanicus subsp. nov., a hydrocarbon-degrading, heavy metal resistant bacterium from hot compost. J Gen Appl Microbiol 2006, 52(4):223-234

6. Goyal S, Dhull SK, Kapoor KK: Chemical and biological changes during composting of different organic wastes and assessment of compost maturity. Bioresour Technol 2005, 96(14):1584-1591.

7. Gupta R, Gupta N, Rathi P: Bacterial lipases: an overview of production, purification and biochemical properties. Appl Microbiol Biotechnol 2004, 64(6):763-781.

8. Salameh M, Wiegel J: Lipases from extremophiles and potential for industrial applications. Adv App/ Microbiol 2007, 61:253-283.

9. Lee $\mathrm{MH}$, Lee $\mathrm{CH}$, Oh TK, Song JK, Yoon JH: Isolation and characterization of a novel lipase from a metagenomic library of tidal flat sediments: evidence for a new family of bacterial lipases. App/ Environ Microbiol 2006, 72(11):7406-7409.

10. Kim EY, Oh KH, Lee MH, Kang CH, Oh TK, Yoon JH: Novel cold-adapted alkaline lipase from an intertidal flat metagenome and proposal for a new family of bacterial lipases. App/ Environ Microbiol 2009, 75(1):257-260.

11. Chu X, He H, Guo C, Sun B: Identification of two novel esterases from a marine metagenomic library derived from South China Sea. Appl Microbiol Biotechnol 2008, 80(4):615-625

12. Hu Y, Fu C, Huang Y, Yin Y, Cheng G, Lei F, Lu N, Li J, Ashforth EJ, Zhang L, et al: Novel lipolytic genes from the microbial metagenomic library of the South China Sea marine sediment. FEMS Microbiol Ecol 72(2):228-237.

13. Arpigny $\mathrm{L}$, Jaeger KE: Bacterial lipolytic enzymes: classification and properties. Biochem J 1999, 343(Pt 1):177-183.

14. Bornscheuer UT: Microbial carboxyl esterases: classification, properties and application in biocatalysis. FEMS Microbiol Rev 2002, 26(1):73-81.

15. Villeneuve P, Muderhwa JM, Graille J, Haas MJ: Customizing lipases for biocatalysis: A survey of chemical, physical and molecular biological approaches. Journal of Molecular Catalysis - B Enzymatic 2000, 9(46):113-148.

16. Nomura N, Shigeno-Akutsu Y, Nakajima-Kambe T, Nakahara T: Cloning and sequence analysis of a polyurethane esterase of Comamonas acidovorans TB-35. Journal of Fermentation and Bioengineering 1998, 86(4):339-345.

17. Howard GT, Crother B, Vicknair J: Cloning, nucleotide sequencing and characterization of a polyurethanase gene (pueB) from Pseudomonas chlororaphis. International Biodeterioration and Biodegradation 2001, 47(3):141-149.

18. Bugg TD: Diverse catalytic activities in the alphabeta-hydrolase family of enzymes: activation of $\mathrm{H} 2 \mathrm{O}, \mathrm{HCN}, \mathrm{H} 2 \mathrm{O} 2$, and O2. Bioorg Chem 2004, 32(5):367-375.

19. Martinez-Martinez I, Navarro-Fernandez J, Garcia-Carmona F, Takami H, Sanchez-Ferrer A: Characterization and structural modeling of a novel thermostable glycine oxidase from Geobacillus kaustophilus HTA426. Proteins 2008, 70(4):1429-1441.

20. Soror SH, Verma V, Rao R, Rasool S, Koul S, Qazi GN, Cullum J: A cold-active esterase of Streptomyces coelicolor $A 3(2)$ : from genome sequence to enzyme activity. J Ind Microbiol Biotechnol 2007, 34(8):525-531.

21. Nakajima-Kambe T, Shigeno-Akutsu Y, Nomura N, Onuma F, Nakahara T: Microbial degradation of polyurethane, polyester polyurethanes and polyether polyurethanes. Appl Microbiol Biotechnol 1999, 51(2):134-140.

22. Kourist R, Dominguez de Maria P, Bornscheuer UT: Enzymatic synthesis of optically active tertiary alcohols: expanding the biocatalysis toolbox. Chembiochem 2008, 9(4):491-498.

23. Henke E, Pleiss J, Bornscheuer UT: Activity of lipases and esterases towards tertiary alcohols: insights into structure-function relationships. Angew Chem Int Ed Engl 2002, 41(17):3211-3213.

24. Pleiss J, Fischer M, Peiker M, Thiele C, Schmid RD: Lipase engineering database: Understanding and exploiting sequence-structure-function relationships. Journal of Molecular Catalysis - B Enzymatic 2000, 10(5):491-508

25. Gong PF, Wu HY, Xu JH, Shen D, Liu YY: Biocatalytic preparation of enantiopure ( $\mathrm{R})$-ketoprofen from its racemic ester by a new yeast isolate Citeromyces matriensis CGMCC 0573. Appl Microbiol Biotechnol 2002, 58(6):728-734.

26. Ogino $\mathrm{H}$, Ishikawa $\mathrm{H}$ : Enzymes which are stable in the presence of organic solvents. J Biosci Bioeng 2001, 91(2):109-116.

27. Zhou J, Bruns MA, Tiedje JM: DNA recovery from soils of diverse composition. Appl Environ Microbiol 1996, 62(2):316-322.

28. Kim MG, Lee EG, Chung BH: Improved enantioselectivity of Candida rugosa lipase towards ketoprofen ethyl ester by a simple two-step treatment. Process Biochemistry 2000, 35(9):977-982.

doi:10.1186/1475-2859-10-41

Cite this article as: Kang et al:: A novel family VII esterase with industrial potential from compost metagenomic library. Microbial Cell Factories 2011 10:41.

\section{Submit your next manuscript to BioMed Central and take full advantage of:}

- Convenient online submission

- Thorough peer review

- No space constraints or color figure charges

- Immediate publication on acceptance

- Inclusion in PubMed, CAS, Scopus and Google Scholar

- Research which is freely available for redistribution 